Mediterranean Journal of Humanities mjh.akdeniz.edu.tr III/1, 2013, 177-188

\title{
The Effect of Parent and Sibling Education Program on Attitudes and Behaviours towards Children with Disabilities
}

\author{
Aile ve Kardeş Eğitimi Programı'nın Engelli Çocuğa Yönelik Tutum ve \\ Davrantşlara Etkisi
}

\section{Rukiye KONUK ER* Sunay YILDIRIM DOĞRU** Fulya TEMEL ${ }^{* * *}$}

\begin{abstract}
This research was carried out in order to examine the effect of The Parent Education Program (PEP) and The Sibling Education Program (SEP) which is given to siblings without disabilities and their parents on the attitudes and behaviours of 10-14 year old siblings without disabilities towards their siblings with disabilities. The Multi subject-multi factor experimental pattern, which is one of experimental models, was applied in this research. The pre-test post-test control group pattern was conducted in this context. The study group consisted of 30 primary school students (experiment-1, experiment-2, and experiment 3) from the central counties of Konya who were 10-14 years old and had a sibling with disabilities and 10 parents (parents of children in experiment-2). The data collecting tools for normal children were: "The Attitude towards Disabled Sibling Scale", "The Schaffer Sibling Behaviour Rating ScaleSibling Form", and data about mothers was collected through, "The Schaffer Sibling Behaviour Rating Scale-Mother Form". Mann Whitney U-Test, Kruskal Wallis Test (H test) and Wilcoxon Signed Ranks Test were used to determine. According to the result, the siblings in the experimental groups display a high increase at their attitudes and behaviours. Children and parents evaluate the general behaviour levels of typically developing children participating in PEP in a similar way.
\end{abstract}

Keywords: Attitude, behavior, disabled child, Parent and Sibling Education Program, siblings

Özet: Bu araştırma Aile Eğitim Programı (AEP) ve Kardeş Eğitim Programı'nın (KEP) 10-14 yaş aralığındaki normal kardeşlerin engelli kardeşine yönelik tutum ve davranışlarına etkisini incelemek amacıyla yapılmıştır. Araştırma çok denekli-çok faktörlü deneysel desen kullanılarak öntest-sontest kontrol gruplu desen üzerinde yürütülmüsşür. Çalışma grubunu, Konya merkez ilçelerinde zihin engelli kardeşi bulunan 10-14 yaş aralı̆̆ındaki 30 ilköğretim okulu öğrencisi ile 10 ebeveyn oluşturmuş̧ur. Veri toplama aracı olarak normal çocuklar için; “Özürlü Kardeşe Yönelik Tutum Ölçeği” ve "Schaffer Kardeş Davranışı Değerlendirme Ölçeği-Kardeş Formu" kullanılırken anneler için "Schaffer Kardeş Davranışı Değerlendirme Ölçeği-Anne Formu" kullanılmıştır. Mann Whitney U-Testi, Kruskal Wallis Testi (H testi) ve Wilcoxon İşaretli Sıralar Testi'nden yararlanılmıştır. Sonuçlara göre deney gruplarındaki kardeşlerin tutum ve davranışlarında artış olmuştur. Çocuklar ve ebeveynler, AEP'te yer alan normal çocukların engelli kardeşlerine yönelik genel davranış düzeylerini benzer şekilde değerlendirmektedirler.

Anahtar sözcükler: Tutum, davranış, engelli çocuk, Aile ve Kardeş Eğitim Programı, kardeş

\footnotetext{
* Dr., Selçuk University, Faculty of Vocational Education, Turkey, rukiyekonuk@gmail.com

** Assoc. Prof. Dr., Dokuz Eylül University, Special Education Department, İzmir, yldrmdogru@gmail.com

*** Prof. Dr., Gazi University, Faculty of Vocational Education, Ankara, ftemel@gazi.edu.tr
} 
This article was announced verbally in the World Conference on New Trends in Science Education (WCNTSE) between the dates $19^{\text {th }}$ and $23^{\text {rd }}$ September last year. The article is written from the doctoral thesis of "The Effect of Parent and Sibling Education Program on Attitudes and Behaviours towards Children with Disabilities" prepared in the department of Child Development and Education in Selcuk University Vocational Social Science Institution.

It will be helpful to evaluate the family as a whole instead of considering parents or children separately in order to understand the family. If parents know the features and competence of their children and see and accept them as they are, a progress can be provided in terms of the development of the children. If family members feel themselves relieved against the problems they face, the effect of this relief will be more on the children with disabilities. In the Parent Education Program, parents must talk about the children with disabilities without feeling embarrassed or bored. When the knowledge of the educator and the life experience of the parents integrate, a correct program that is appropriate for the children with disabilities is provided (Anonymous, 2007).

Here is a fact that studies related to special education reveal: the group, which is always ignored in the family, consists of typically developing children. Possible effects of the presence of a child with disabilities in the family on sibling relations are important because of the nature of this relationship. Many factors direct this relationship. One of these factors is the involvement of a child with disabilities in the family. Brothers and sisters experience a wide range of feelings. These feelings are; anger, resentment, disappointment, and even guiltiness. Siblings are worried about the future of the sibling with disabilities and they are concerned about having the disability as well (Kuçuker, 1997; Moore, Howard, \& McLaughlin, 2002).

Siblings need information about the situation and the future of their siblings with disabilities. They need trustworthy information, to answer their own questions and the questions that other people ask of them and to plan their own future. These children must receive the required and clear information relating to the present situation of their siblings with disabilities (Meyer, 1997; Moore et alii, 2002; Meyer, \& Vadasy, 2006).

Limiting siblings with disabilities of typically developing siblings with only programs giving educational support may cause annoying situations for those siblings without disabilities. Continually participating in programs that focus on their siblings brings negative feelings and attitudes, and causes them to feel that their lives will be always based on their siblings with disabilities. Accordingly, siblings need programs in which they will have the opportunity to be with people that will understand themselves in an entertaining environment where they both will get rid of the negative things they experience and see social life without problems. Considering the programs prepared in terms of these requirements, the general purpose of this research is to look for an answer to the question "Do the Sibling Education Programs (SEP) and The Parent Education Programs (PEP) affect the attitudes and behaviours of siblings towards siblings with disabilities?".

\section{METHOD}

\section{Model of Study}

Multi subject-multi factor experimental pattern, which is one of the experimental models, was applied in this research. The pre-test - post-test control group pattern was conducted in this context. The independent variable of this research is The Sibling Education Program and the Parent Education Program. The dependent variables, which are supposed to be affected by the program, are the attitudes and behaviours of typically developing siblings towards siblings with disabilities 
and the opinions of parents about the behaviours of the typically developing children.

\section{Participants}

There are 3 different groups in this research. One of the groups is the control group; the other two groups are the experimental groups. One of the experimental groups consisted of only typically developing children having siblings with disabilities, and the other group included typically developing children and their parents.

This researched was conducted in Konya between 2009 and 2010 on a study group including in total 40 participants. 10 of the participants were parents and 30 primary school students of the ages of 10-14 having an intellectual handicap. Two separate groups were constructed. One of these established groups was appointed as the control group and the other was appointed as experiment-1 group [children participated in Sibling Education Program (SEP)] by again using the random selection method. The experiment-2 group [children participated in Parent Education Program (PEP)] consisted of 10 different parents having children that participate in special education and rehabilitation centres and 10 typically developing children attending a primary school of these parents.

\section{Data Collection Tools}

\section{a) The Attitude towards Disabled Sibling Scale (ATDSS)}

The attitude scale prepared by Kuçuker (1997) and tested in terms of validity-reliability consists of 28 items and is appropriate for typically developing children who are aged between 12 - 21 and have siblings with educable mentally handicaps. This research was conducted on typically developing children who are aged between 10-14 and have siblings with mild and moderate intellectual (mental) handicaps. Accordingly, the validity-reliability study was again done in order to completely meet the objectives of the research. Factor analysis (The Principal Component Analysis) was used in order to provide structural validity of the scale, and expert opinion were used to provide content and face validity. In consequence of structural validity and reliability studies, the dimensions of the attitude scale were decreased and some items were eliminated. By taking expert opinion, 12 items below 0.30 that affected the reliability and validity of the scale in a negative way were eliminated. This process reduced the number of items to 16 . The dimensions, which showed inconsistency and overlapped with each other, were eliminated from the scale. In consequence of the factor analysis, the total variance explanation rate under single factor was found as $52 \%$, and the Cronbach Alpha reliability coefficient was 0.94 . The Attitude towards Disabled Sibling Scale was rearranged in terms of the target group and objectives of this research, converted into a one-dimensional and 16-item Likert type attitude scale, and used in this way in this research.

\section{b) The Schaeffer Sibling Behaviour Rating Scale}

The Schaeffer Sibling Behaviour Rating Scale, which was prepared by Schaeffer-Edgerton (1979), developed by Mc Hale et alii, (1986) and adapted into Turkish by Ahmetoğlu (2005), consists of 30 items and 5 sub-dimensions in order to evaluate the relationships of typically developing children with their siblings with disabilities. The measuring instrument was applied to both siblings and mothers. The validity and reliability of the scale was tested again. In consequence of conducted validity and reliability studies, the dimensions of the scale were reduced and some items were eliminated. By taking the opinion of the experts, 10 items below 0.30 that affected the reliability and validity of the scale in a negative way were eliminated. This process reduced the number of items to 20 . The dimensions showing inconsistency and overlapping 
were eliminated from the scale. The scale was gathered under three dimensions in the light of opinions of assessment and evaluation experts, research methodology experts and experts in the field of study. The total variance explanation rate of the scale was $61 \%$, and factor load value of the items taking place in the scale ranges from 0.32 to 0.70 . The Cronbach Alpha reliability coefficient for the entire scale was 0.88 .

\section{Data collection}

Two different experimental groups were established. Sibling Education Program (SEP) prepared in Experiement-1 group was applied only to normal children, and Parent Education Program (PEP) was conducted on the Experiment-2 group. In addition to parents, the Parent Education Program also included the program for siblings.

\section{Analyzing the Data}

Mann Whitney U-Test was used in binary group comparisons to determine pre-test and post-test scores of the attitude scale and behaviour rating scale, and Kruskal Wallis Test ( $\mathrm{H}$ test) was used for triple group comparisons. Pre-test post-test score averages were compared through Wilcoxon Signed Ranks Test. While testing the differences, the significance level was accepted as $\alpha=0.05$.

\section{FINDINGS}

\section{The Effect of Programs on Attitudes of Typically Developing Children towards Siblings with Disabilities}

Table 1. Wilcoxon Signed Ranks Test Results Related to the Attitude Pre-test Post-test Scores of Control and Experimental Groups Towards Siblings With Disabilities.

\begin{tabular}{|c|c|c|c|c|c|c|c|}
\hline Program & Pre-test-Post-test & $N$ & $\begin{array}{c}\text { Rank } \\
\text { Average }\end{array}$ & $\begin{array}{l}\text { Rank } \\
\text { Total }\end{array}$ & Z & $\mathrm{P}$ & Significance \\
\hline \multirow{3}{*}{$\overrightarrow{\vec{I}}$} & Negative Rank & 0 & 0,00 & 0,00 & \multirow{3}{*}{$2.807^{*}$} & \multirow{3}{*}{0,005} & \multirow{3}{*}{$\mathrm{P}<0.05$} \\
\hline & Positive Rank & 10 & 5,50 & 55,00 & & & \\
\hline & Equal & 0 & & & & & \\
\hline \multirow{3}{*}{ 空 } & Negative Rank & 0 & 0,00 & 0,00 & \multirow{3}{*}{$2.810^{*}$} & \multirow{3}{*}{0,005} & \multirow{3}{*}{$\mathrm{P}<0.05$} \\
\hline & Positive Rank & 10 & 5,50 & 55,00 & & & \\
\hline & Equal & 0 & & & & & \\
\hline \multirow{3}{*}{ 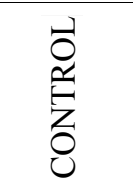 } & Negative Rank & 2 & 5,50 & 11,00 & \multirow{3}{*}{0.990} & \multirow{3}{*}{0,322} & \multirow{3}{*}{ - } \\
\hline & Positive Rank & 6 & 4,17 & 25,00 & & & \\
\hline & Equal & 2 & & & & & \\
\hline
\end{tabular}

$\mathrm{P}<0.05\left(^{*}\right)$ sign shows that the difference is significant.

In Table 1, it is seen that post-test attitude scores of all the children in experiment 1(SEP) and experiment-2 (PEP) groups are higher than the pre-test attitude scores, and the sign is $(+)$. When rank averages and total of the scores are taken into consideration and the $\mathrm{z}$ values are calculated in order to see if the difference is statistically significant $\left[\left(\operatorname{KEP}_{(\mathrm{z})}=2.807, \mathrm{p}<0.05\right) ;\left(\mathrm{AEP}_{(\mathrm{z})}=2.810\right.\right.$, $\mathrm{p}<0.05$ ], it is seen that the attitude scores of experiement-1(SEP) and experiment-2 (PEP) before and after the experiment are significant at the level of $\alpha=0.05$. In the control group, it is observed that there is not a significant difference among the attitude pre-test-post-test scores of the 
typically developing children towards siblings with disabilities. When rank averages and rank total are considered, it is understood that when compared with pre-test scores, post-test scores of 2 of 10 children decreased, 6 of 10 children increased and 2 of 10 children remained stable. Otherwise the change/differentiation in the scores of the children was not found to be significant.

Table 2. Comparison Of Attitude Scores (Post-test) Of Control And Experimental Groups (Sep-Pep) Towards Siblings With Disabilities (The Kruskal Wallis H Test).

\begin{tabular}{|c|c|c|c|c|c|c|}
\hline Groups & N & Rank Average & Sd & $X^{2}$ & P & Significance \\
\hline SEP (1) & 10 & 21,05 & & & & $1-3$ \\
PEP (2) & 10 & 18,25 & \multirow{2}{*}{2} & 13.911 & 0.001 & $2-3$ \\
\hline CONTROL (3) & 10 & 7,20 & & & & \\
\hline
\end{tabular}

$\mathrm{P}<0.05$

As it is seen when Table 2 is examined, there are differences among the post-test scores related to the attitudes of the groups. According to the result of The Kruskal Wallis H-Test which is conducted in order to compare independent groups with the purpose of determining if these differences are significant, the difference among the groups is significant at the level of $\alpha=0.05$ $\left(X^{2}{ }_{(2)}=13.911 ; \mathrm{p}<0.05\right)$. When the rank averages of the control and experimental groups are examined, it is possible to say that the children in the experimental groups have higher attitude scores than the children in the control group possess. The Mann Whitney U-Test was applied for pair-group comparison to determine the cause of the difference. According to the collected results, the control group is the cause of the difference. There are significant differences between the control group and experiement-1 (SEP), and control group and experiment-2 (PEP). There is not a considerable difference between the experimental groups.

\section{The Effect of Sibling Education Programs on the General Behaviours of Typically Developing Children Relating to the Sibling with Disabilities}

In the research, the general behaviours of the typically developing children in the control and experimental groups related to the siblings with disabilities were examined and the attempt was made to determine if sibling education program which was carried out through two different methods would affect the general behaviours of typically developing children relating to siblings with disabilities. The general behaviour levels of typically developing children were determined in terms of parental and their own opinions; the attempt was made to find if there is a change in terms of behaviour dimensions including (1) keeping away (avoidance), (2) aggression and (3) being concerned.

Table 3. The Wilcoxon Signed Ranks Test Results Related To The General Behaviour Pre-test Posttest Scores Comparison Of The Control And Experimental Groups About Siblings With Disabilities

\begin{tabular}{|c|c|c|c|c|c|c|c|c|c|}
\hline Group & Program & $\begin{array}{l}\text { Behaviour } \\
\text { Evaluation }\end{array}$ & Pre-test-Post-test & $N$ & $\begin{array}{c}\text { Rank } \\
\text { Average }\end{array}$ & $\begin{array}{l}\text { Rank } \\
\text { Total }\end{array}$ & Z & $\mathrm{P}$ & $\begin{array}{l}\text { Signifi- } \\
\text { cance }\end{array}$ \\
\hline \multirow{6}{*}{ 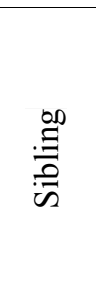 } & \multirow{6}{*}{$\overrightarrow{\tilde{y}}$} & \multirow{3}{*}{$\begin{array}{c}\text { Avoidance } \\
\text { (keeping away) }\end{array}$} & Negative Rank & 9 & 6,00 & 54,00 & \multirow{3}{*}{2.712} & \multirow{3}{*}{$0,007 *$} & \multirow{3}{*}{$\mathrm{P}<0.05$} \\
\hline & & & Positive Rank & 1 & 1,00 & 1,00 & & & \\
\hline & & & Equal & 0 & & & & & \\
\hline & & \multirow{3}{*}{ Aggression } & Negative Rank & 6 & 3,50 & 21,00 & \multirow{3}{*}{2.214} & \multirow{3}{*}{$0,027^{*}$} & \multirow{3}{*}{$\mathrm{P}<0.05$} \\
\hline & & & Positive Rank & 0 & 00 & 00 & & & \\
\hline & & & Equal & 4 & & & & & \\
\hline
\end{tabular}




\begin{tabular}{|c|c|c|c|c|c|c|c|c|}
\hline & \multirow{3}{*}{ Being Concerned } & Negative Rank & 2 & 4,75 & 9,50 & \multirow{3}{*}{1.543} & \multirow{3}{*}{0,123} & \multirow{3}{*}{-} \\
\hline & & Positive Rank & 7 & 5,07 & 35,50 & & & \\
\hline & & Equal & 1 & & & & & \\
\hline \multirow{9}{*}{$\frac{0}{\frac{1}{2}}$} & \multirow{3}{*}{$\begin{array}{c}\text { Avoidance } \\
\text { (keeping away) }\end{array}$} & Negative Rank & 9 & 6,00 & 54,00 & \multirow{3}{*}{2.706} & \multirow{3}{*}{$0,007 *$} & \multirow{3}{*}{$\mathrm{P}<0.05$} \\
\hline & & Positive Rank & 1 & 1,00 & 1,00 & & & \\
\hline & & Equal & 0 & & & & & \\
\hline & \multirow{3}{*}{ Aggression } & Negative Rank & 7 & 4,00 & 28,00 & \multirow{3}{*}{2.388} & \multirow{3}{*}{$0,017 *$} & \multirow{3}{*}{$\mathrm{P}<0.05$} \\
\hline & & Positive Rank & 0 & 0,00 &, 000 & & & \\
\hline & & Equal & 3 & & & & & \\
\hline & \multirow{3}{*}{ Being Concerned } & Negative Rank & 2 & 1,75 & 3,50 & \multirow{3}{*}{2.449} & \multirow{3}{*}{$0,019 *$} & \multirow{3}{*}{$\mathrm{P}<0.05$} \\
\hline & & Positive Rank & 8 & 6,44 & 51,50 & & & \\
\hline & & Equal & 0 & & & & & \\
\hline \multirow{9}{*}{ 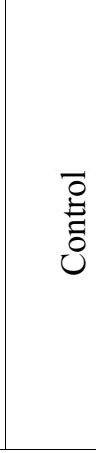 } & \multirow{3}{*}{$\begin{array}{c}\text { Avoidance } \\
\text { (keeping away) }\end{array}$} & Negative Rank & 2 & 2,00 & 4,00 & \multirow{3}{*}{1.382} & \multirow{3}{*}{0,167} & \multirow{3}{*}{$\mathrm{P}>0.05$} \\
\hline & & Positive Rank & 4 & 4,25 & 17,00 & & & \\
\hline & & Equal & 4 & & & & & \\
\hline & \multirow{3}{*}{ Aggression } & Negative Rank & 1 & 2,50 & 2,50 & \multirow{3}{*}{1.000} & \multirow{3}{*}{0,317} & \multirow{3}{*}{$\mathrm{P}>0.05$} \\
\hline & & Positive Rank & 3 & 2,50 & 7,50 & & & \\
\hline & & Equal & 6 & & & & & \\
\hline & \multirow{3}{*}{ Being Concerned } & Negative Rank & 6 & 4,92 & 29,50 & \multirow{3}{*}{0.857} & \multirow{3}{*}{0,392} & \\
\hline & & Positive Rank & 3 & 5,17 & 15,50 & & & $\mathrm{P}>0.05$ \\
\hline & & Equal & 1 & & & & & \\
\hline & & Negative Rank & 9 & 5,00 & 45,00 & & & \\
\hline & (keening away) & Positive Rank & 0 & ,00 &, 00 & 2.670 & $0,008 *$ & $\mathrm{P}<0.05$ \\
\hline & & Equal & 1 & & & & & \\
\hline & & Negative Rank & 7 & 4,00 & 28,00 & & & \\
\hline $\overrightarrow{\bar{d}}$ & Aggression & Positive Rank & 0 & 0,00 & 0,00 & 2.379 & $0,017 *$ & $\mathrm{P}<0.05$ \\
\hline$\sim$ & & Equal & 3 & & & & & \\
\hline & & Negative Rank & 1 & 4,00 & 4,00 & & & \\
\hline & Being Concerned & Positive Rank & 9 & 5,67 & 51,00 & 2.400 & $0,016^{*}$ & $\mathrm{P}<0.05$ \\
\hline & & Equal & 0 & & & & & \\
\hline
\end{tabular}

(*) Sign means that the difference is significant.

As it is understood when Table 3 is examined, Sibling Education Program (SEP) applied in experiment- 1 caused a meaningful decrease in the behaviours of keeping away from the sibling with disabilities $\left(\mathrm{KEP}_{\mathrm{z} z}=2.712, \mathrm{p}<0.05\right)$ and showing aggression towards the sibling with disabilities $\left(\mathrm{KEP}_{(\mathrm{z})}=2.214, \mathrm{p}<0.05\right)$ in comparison with normally developing children. A certain increase is observed in the behaviours of being concerned with the sibling with disabilities $\left(\mathrm{KEP}_{(\mathrm{z})}=1.543, \mathrm{p}<0.05\right)$ but this increase is not significant. Once again, when compared with typically developing children, Parent Education Program (PEP) carried out in the experiment-2 provided a decrease in the behaviour of keeping away from the sibling with disabilities $\left(\mathrm{AEP}_{(\mathrm{z})}\right.$ $=2.706, \mathrm{p}<0.05)$ and showing aggression towards the sibling with disabilities $\left(\mathrm{AEP}_{(\mathrm{z})}=2.388\right.$, $\mathrm{p}<0.05$ ) but, on the other hand, it provided a meaningful increase in the behaviours of being concerned with the sibling with disabilities $\left(\mathrm{AEP}_{(\mathrm{z})}=2.449, \mathrm{p}<0.05\right)$.

There was no significant difference in the behaviours including keeping away, showing aggression and being concerned of the children in the control group in which no education programs were applied but only informal education was given. 
According to the opinions of the parents who participated in the Parent Education Program, it is seen that; Parent Education Program (PEP) applied in experiment-2 caused a meaningful decrease in the behaviours of keeping away from the sibling with disabilities $\left(\mathrm{AEP}_{(\mathrm{z})}=2.670\right.$, $\mathrm{p}<0.05)$ and showing aggression towards the sibling with disabilities $\left(\operatorname{AEP}_{(\mathrm{z})}=2.379, \mathrm{p}<0.05\right)$ of the typically developing children, on the other hand, it caused a considerable increase in the behaviours of being concerned with the sibling having disabilities $(\operatorname{AEP}(z)=2.400, p<0.05)$.

Table 4. Comparison Of General Behaviour Achievement Scores (Post-Test) Of Control And Experimental Groups Related To The Siblings With Disabilities (The Kruskal Wallis H Test).

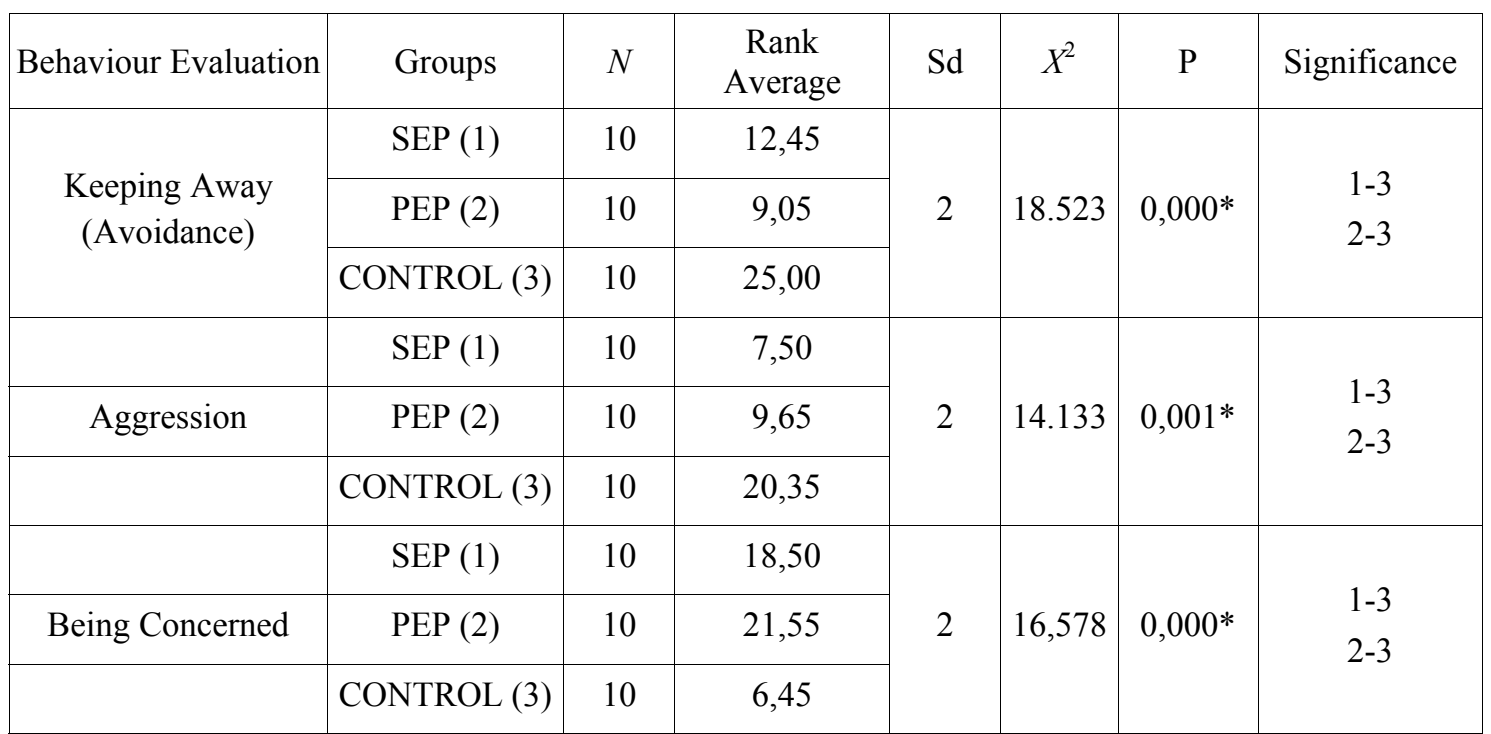

(*) $\mathrm{P}<0.05$

As it is understood from Table 4, there are differences among the post-test scores related to the general behaviour levels of the groups. According to the result of The Kruskal Wallis H-Test which is conducted in order to compare independent groups with the purpose of determining if these differences are significant, the difference among all groups is significant at the level of $\alpha=0.05$ in terms of behavioural dimensions including keeping away (avoidance) $\left(\mathrm{X}^{2}{ }_{(2)}=18.523\right.$; $\mathrm{p}<0.05)$, aggression $\left(\mathrm{X}^{2}{ }_{(2)}=14.133 ; \mathrm{p}<0.05\right)$ and being concerned $\left(\mathrm{X}^{2}{ }_{(2)}=16.578 ; \mathrm{p}<0.05\right)$. The Mann Whitney U-Test was applied in pair-group comparisons to determine the cause of the difference. The collected results show that the cause of the difference is the control group.

Table 5. Mann Whitney U-Test Results Related To The Of General Behaviour Achievement Score (Post-test) Comparison Of Typically Developing Children That Participated In The Experiment-2 Group (Pep) Towards Their Mentally Handicapped Siblings In Accordance With The Children And Parents Who Attended The Experiment-2 Parent Education Program

\begin{tabular}{|c|c|c|c|c|c|c|c|}
\hline $\begin{array}{l}\text { Behaviour } \\
\text { Evaluation }\end{array}$ & Post-test & $N$ & Rank Average & $\begin{array}{l}\text { Rank } \\
\text { Total }\end{array}$ & U & $\mathrm{P}$ & Significance \\
\hline \multirow{2}{*}{$\begin{array}{l}\text { Keeping Away } \\
\text { (Avoidance) }\end{array}$} & Child & 10 & 11,05 & 110,50 & \multirow{2}{*}{44.500} & \multirow{2}{*}{0,684} & \multirow{2}{*}{$\mathrm{P}>0.05$} \\
\hline & Parents & 10 & 9,95 & 99,50 & & & \\
\hline \multirow{2}{*}{ Aggression } & Child & 10 & 8,30 & 83,00 & \multirow{2}{*}{28.00} & \multirow{2}{*}{0,710} & \multirow{2}{*}{$\mathrm{P}>0.05$} \\
\hline & Parents & 10 & 12,70 & 127,00 & & & \\
\hline \multirow{2}{*}{ Being Concered } & Child & 10 & 9,95 & 99,50 & \multirow{2}{*}{44.500} & \multirow{2}{*}{0,676} & \multirow{2}{*}{$\mathrm{P}>0.05$} \\
\hline & Parents & 10 & 11,05 & 110,50 & & & \\
\hline
\end{tabular}


The differences among the general behaviour achievement post-test scores of children that participated in the experiment-2 group (PEP) towards their mentally handicapped siblings are seen in Table 5. The Mann Whitney U-Test was carried out in order to compare two independent groups with the purpose of determining if the difference is meaningful. The results showed that the difference between the groups (parent and typically developing sibling) is significant at the level of $\alpha=0.05$ and is not significant for any behaviour dimensions.

\section{DISCUSSION}

It is seen that post-test attitude scores of all the children in experiment 1(SEP) and experiment-2 (PEP) groups are higher than the pre-test attitude scores, and the related sign is $(+)$. It is possible to say that the observed changes related to the attitude pre-test post-test scores of typically developing children towards siblings with disabilities can be attributed to activities which were carried out in the experiment-1 (SEP) and experiment-2 (PEP) groups, and a positive change can be provided by the help of Sibling Education and Parent Education Programs. The conducted researches (Handlers, \& Austin, 1980; Feidler Simpson, 1987; Beh-Pajooh, 1991; Pruchno, et alii 1996; Küçüker, 1997; Moore et alii, 2002; Lyons-Sjostrom, 2003; Ahmetoğlu, 2004) report that sibling support groups are effective in displaying positive attitudes by siblings towards their siblings with disabilities.

When post-test score averages of the control and experimental group are compared, it is seen that the children in the experimental groups had higher attitude scores than children in the experimental group. The results show that the reason takes its source from the control group. There is a significant difference between the control group and experiment-1 (SEP) and again between the control group and experiment-2 (PEP). There is not a considerable difference between the experimental groups. Accordingly, it is understood that the sibling education programs applied in experimental groups increases the positive attitudes of typically developing children towards siblings with intellectual disabilities, and there were not any positive attitude changes in the control group because the control group did not receive any education programs. It can be said that both programs were successful and met the objective in experimental groups, and were also effective on teaching and forming attitudes. This is why the expected difference did not appear between the experimental groups. The parents who participated in PEP were supported to help their typically developing children and perform correct applications for the children with disabilities. It is thought that this situation provides a positive reaction upon parents in PEP and helps siblings in SEP think their parents exhibit positive attitudes towards their children. Thus, this reason might affect both groups in terms of being more successful.

Sibling Education Program (SEP) applied in experiment-1 caused a meaningful decrease in the behaviours of keeping away from the sibling with disabilities and showing aggression towards the sibling with disabilities in comparison with normally developing children. Once again, when compared with the typically developing children, Parent Education Program (PEP) carried out in experiment-2 provided a decrease in the behaviours of keeping away from the sibling with disabilities and showing aggression towards the sibling with disabilities but, on the other hand, it provided a decrease in the behaviours of being concerned with the sibling with disabilities. It is possible to say that the programs, which were applied, are effective in changing the behaviours of siblings in a positive way. This is because the behaviours of siblings who know how to communicate in the family must be aware of the competence of the siblings with disabilities and know how to change behavior in an expected positive way. Pursuant to the objectives of the research, it is thought that experiencing the conditions in which typically developing children deal with their siblings with disabilities, take responsibilities of them, have 
information about their development, see how they would behave if they were in the same situation, will be important in changing the behaviour of siblings towards their siblings with disabilities.

Noller, \& Northfield (2000) have determined that those adolescent siblings who are satisfied with their relationship with their siblings with disabilities are those who spend more time in communication with them. Krauss, Seltzer, Gordon, \& Freidman (1996) have conducted a study in which they tried to determine the sibling relationships and role expectations for the future of 140 typically developing adult siblings of mentally handicapped children. According to the findings of this research, it has been determined that those typically developing siblings that plan to live with their siblings with disabilities in the future are those who spend more time with their siblings with disabilities.

According to the opinions of the parents who participated in the Parent Education Program, it is seen that; Parent Education Program (PEP) applied in experiment-2 provided a meaningful decrease in the behaviours of keeping away from the sibling with disabilities and showing aggression towards the sibling with disabilities of typically developing children. In the research conducted by Ahmetoğlu (2004), it is reported that mothers and typically developing children have a common understanding in terms of sibling relations in the dimensions of physical aggression towards the sibling with disabilities and keeping away from the sibling with disabilities.

According to both parents and typically developing children who participated in the education program, the applications of SEP and PEP conducted on the experimental groups affected the general behaviours of typically developing children towards siblings with disabilities in a positive manner. It is possible to say that learning is provided, a positive change is observed in the attitudes of typically developing children towards their siblings with disabilities, and these are reflected in the general behaviours towards the disabled siblings. The siblings of mentally handicapped children and the siblings of children without mental disabilities were evaluated in terms of siblings relations that they experienced in the study carried out by Rimmerman (2001). It was determined that the siblings of mentally handicapped children were more sincere in their interactions with their siblings and in a closer relationship, and participated in more entertaining activities by helping them than the siblings in the other group.

There are differences among the post-test scores related to the general behaviour levels of the study groups. The collected results show that the cause of the difference is the control group. Since the children in the control group did not gain the required behaviours sufficiently in the contexts of keeping away from the sibling with disabilities, showing aggressive behaviours and being concerned with siblings with disabilities, there is a significant difference between the control and experimental groups.

Providing conditions in which typically developing children have more positive experiences with siblings with disabilities will be effective on reducing negative behaviours that they exhibit (www.childtrends.org. Pearson, \& Sternberg, 1986; McGillicuddy-De Lisi, 1993; Powell, \& Gallagher, 1993; Burke, \& Montgomery, 2001; Hannah, \& Midlarsky, 2005). Thus, Civelek (1990) aimed at determining the effect of integrating mentally handicapped children with their typically developing peers and informing about this issue on social acceptance of typically developing children towards children with disabilities. According to the results collected from the research, the typically developing children from the integrated and informed group displayed more social acceptance towards their mentally handicapped friends than the typically developing children did.

To explain the main reason why the expected difference between the experimental groups 
did not appear, it can be said that both programs were successful and met the objective. But, the excessive responsibilities and concern in the families prevent the complete assimilation of the information, and conditions involving concern can be experienced more in such situations. The presence of conditions such as whether the families both in SEP and PEP groups have equal features, and uncertain concern levels of family groups may also cause this result. The research carried out by Ahmetoğlu (2004) has proved that parental educational status, income level of the family, occupational status of parents are important factors affecting sibling relations.

There were no significant differences between the post-test scores related to the general behaviour success of the parents and normally developing children in Experiment-2 (PEP) group towards children with mental disabilities. This means that the children and parents evaluate the general behaviour levels of the typically developing children in a similar manner and there is a consistency among their opinions. It is possible to say that the siblings and parents that took PEP in the experiment-2 group, that their general behaviours towards those children with disabilities increased positively. That the program was effective on siblings and their parents who joined the program and the information requirement, which is necessary to know how the general behaviours must be, was met, are the points that can be obtained from this result. Thus, Howe, Karos, \& Aquan-Assee (2010) investigated the consistency between the child perception and maternal perception of sibling relation quality, and the connection among the daily interactions of siblings. Their research included 40 healthy siblings and their mothers. The results showed that there was a consistency between the mothers and siblings in perceiving positive sides of the real nature of sibling relations, and this means that there is a consistency among sibling relations towards the sibling with disabilities from the mothers' point of view.

\section{CONCLUSION}

In consequence of sibling education program (SEP) and parent education program (PEP) carried out in the experimental groups, it is noted that while there is a meaningful increase in the attitude and behaviours of typically developing children in these groups towards mentally handicapped children, there is not a meaningful increase for the control group. According to the parents participated in the PEP, the conducted parent education program reduced the behaviours of showing aggression toward siblings with disabilities and keeping away from the sibling with disabilities in a positive way and changed them into the behaviour of being concerned. Both children and parents evaluate the general behaviour levels of typically developing children participating in PEP in a similar way. 


\section{REFERENCES}

Ahmetoğlu, E. (2004). The Evaluation of the Perception of Mentally Retarted Children's SiblingRelationship According to their Mothers and Siblings. Unpublished PhD. Thesis. Ankara University, Institute of Science, Ankara.

Anonymous. (2007). “Advocating for Your Child with a Disability Makes a Difference”. The Exceptional Parent, Mar. 37(3), 66-67.

Beh-Pajooh, A. (1991). "The Effect of Social Contact on College Students' Attitudes Toward Severly Handicapped Students and their Educational Integration". Journal of Mental Deficiency Research, 35, 338-352

Benderix, Y., \& Sivberg, B. (2007). "Siblings' Experiences of Having a Brother or Sister with Autism and Mental Retardation: A Case Study of 14 Siblings from Five Families". International Pediatric Nursing. 22 (5), 410-418.

Burke, P., \& Montgomery, S. (2001). "Brothers and Sisters: Supporting the Siblings of Children With Disabilities". Practice, 13 (1), 27-38.

Burke, P. (2009). "Brothers and Sisters of Disabled Children: The Experience of Disability by Association". British Journal of Social Work, 1-19.

Civelek, A. H. (1990). The Effects of Informing the Normal Children about The Social Acceptance of Mentally Retarded Children who can be Educated and the Integration of the two groups in Physical Education and Painting Classes. Unpublished PhD. Thesis, Institute of Social Sciences, Ankara University, Ankara.

Demirel, O. (2006). Curriculum Development in Education, Ninth Edition. Ankara: Pegem press.

"Guide to Effective Programs for Children and Youth"- Untitled Program for Siblings of Children with Disabilities, www.childtrends.org. Accessed: March 2010.

Fiedler, C. R., \& Simpson, R. L. (1987). "Modifying Attitudes of Nonhandicapped High School Students Toward Handicapped Peers". Exceptional Children, 53, 342-349.

Handlers, A., \& Austin, K. (1980). "Improving Attitudes of High School Students Toward their Handicapped Peers”. Exceptional Children, 47 (3).

Hannah, M. E., \& Midlarsky, E. (2005). "Helping by Siblings of Children with Mental Retardation". American Association on Mental Retardation, 110 (2), 87-99.

Howe, N., Karos, L. K., \& Aquan-Assee, J. (2010). "Sibling Relationship Quality in Early Adolescence: Child and Maternal Perceptions and Daily Interactions". Infant and Child Development (Published online in Wiley InterScience).

Krauss, M. W., Seltzer, M. M., Gordon, R., \& Freidman, D. H. (1996). "Binding Ties: The roles of Adult Siblings of Persons with Mental Retardation". Mental Retardation, 34 (2), 83-93.

Kucuker, S. (1997). The Effects of Informational Psychological Counseling Program on Siblings of Mentally Retarded Children's Knowledge Level Regarding being Disable and the Attitudes Towards their Disabled Siblings. Unpublished PhD. Thesis, Ankara University, School of Social Sciences, Ankara.

Lyons-Sjostrom, K. A. (2003). “Adjustment in Siblings of Children with Disabilities". Degree of Doctor Thesis. The Chicago School of Professional Psychology.

McGillicuddy-De Lisi, A. V. (1993). "Sibling Interactions and Children's Communicative Competency". Applied Developmental Psychology, 14 (3), 365-383.

McHale S., Sloan J., \& Simeonsson R. J. (1986) "Sibling Relationships of Children with Autistic, Mentally Retarded, and nonhandicapped Brothers and Sisters". Journal of Autism and Developmental Disorders, 16 (4), 399-415.

Meyer, D. J. (1997). Views from Our Shoes. United States of America: Woodbine House.

Meyer, D. J., \& Vadasy, P. F. (2006). Sibshops - Workshops for Siblings of Children with Special Needs. United States of America: Paul H. Brookes Publishing.

Moore, L. M., Howard, V. F., \& McLaughlin, T. F. (2002). "Siblings of Children with Disabilities: A Review and Analysis". International Journal of Special Education, 17 (1), 49-63.

Noller, P. \& Northfield, K. (2000). "Young Adult Sibling Relationships and Individual Adjustment". Eds. 
D. Ngaire, M. Innesand, \& I. Walker, Australian Journal of Psychology. $5^{\text {th }}$ Annual Meeting of the Society of Australasian Social Psychologists. Fremantle, (14), 27-30, April 2000.

Pearson, J. E., \& Sternberg, A. (1986). “A Mutual Help Project for Families of Handicapped Children”. Journal of Counseling and Development, 65 (4), 213-216.

Powell, T. H., \& Gallagher, P. A. (1993). Brother and Sisters: A Special Part of Exceptional Families. Baltimore: Brookes Publishing Company.

Pruchno, R. A., Patrick, J. H., \& Butant, C. J. (1996). “Aging Women and their Children with Chronic Disabilities". Family Relations, 45, 318-326.

Rimmerman, A. (2001). "Involvement with Role Perceptions Towards Adult Sibling with and without Mental Retardation”. Journal of Rehabilitation, 67 (2).

Schaefer, E. S., \& Edgerton, M.E. (1979). Marital Autonomy and Relatedness Inventory. Princeton, NJ: Educational Testing Service.

Stoneman, Z., Brody, G. H., Davis, C. H., \& Crapps, J. M. (1989). "Role Relations Between Children Who Are Mentally Retarded and their Older Siblings: Observations in Three in-home Contexts". Research in Developmnetal Disabilities, 10 (1), 61-76. 